\title{
Presence and Lingering: Psychoanalysis in a Mindfulness Frame
}

\author{
Chin $\mathrm{Li}^{1}$ \\ Formerly Consultant Clinical Psychologist
}

\begin{abstract}
Nowadays mindfulness has become a constituent element in various forms of psychotherapy, including psychoanalysis. This essay is my attempt to think about psychoanalysis and mindfulness together, from the starting point of Freud's recommendation of "evenly hovering attention" as the essential psychoanalytic stance. I will look at how mindfulness and psychoanalysis could enrich each other, with a view to placing them within a framework of listening practice that might contribute to our understanding of psychotherapy.
\end{abstract}

\section{Introduction}

It is well-known that the phrase "talking cure" ${ }^{2}$ has originated from psychoanalysis, and now "talking therapy" is a term widely used in public discourses. In relation to talking, mindfulness practice could be characterised as aiming at releasing the practitioner from the bondage of concepts and words, thereby rendering talking unnecessary, whereas psychoanalysis, as the original talking therapy, is "full of words" so to speak. Does that mean they are diametrically opposite? To pursue this question, it is useful to consider the idea of silence and listening in the practice of both disciplines.

Sara Maitland, in her remarkable work A Book of Silence, has said the following:

Psychoanalysts (and other therapists)... create and hold the free silence in which the subjects of the process may struggle to name themselves... During my brief brush with psychoanalysis in the 1980s I myself never encountered this liberating silence... Despite this caveat, the capacity to create such a listening silence is a strange and beautiful thing. So many people, when I have asked them about

${ }^{1}$ Correspondence concerning this article should be addressed to Dr. Chin Li, Email: Chinkeung.Li@gmx.com

2 This is the phrase that Josef Breuer's patient Anna 0 (Bertha Pappenheim) had used to describe the therapy Breuer did with her; sometimes she would call it, jokingly, "chimney-sweeping". Breuer has mentioned this in the 1895 text Studies on Hysteria he and Freud co-authored.

Language and Psychoanalysis, 2019, 8 (1), 4-29.

http://dx.doi.org/10.7565/landp.v8i1.1590 
positive experiences of silence, have mentioned this psychoanalytic silence...

(Maitland, 2008, p. 248, emphasis added)

Maitland describes psychoanalytic silence as a listening silence or liberating silence. Many analysts would agree that such silence is part of the analytic concept of "evenly hovering attention" which Freud recommends. In the case of mindfulness, silence is central to its practice, as staying in the present with an unoccupied mind requires a wordless listening that encompasses all that there is, leading to an experience of inner liberation. ${ }^{3}$ Thus the two disciplines may have an affinity for one another.

"Through silence we speak" - this phrase captures vividly the immense potential of silence in the context of psychotherapy. While it is not my intention to review the literature on silence in psychotherapy, ${ }^{5}$ it is useful to mention a classic paper by a colleague of Freud, Theodor Reik (1927/1968), who has discussed the psychological meaning of a patient's silence. To Reik, silences during therapy are emotionally significant and waiting in silence is far more important a task for the therapist than filling the session with words.

Silence and the meditative stance enable the therapist to speak, when appropriate, from a truly listening frame. Echoing Freud's evenly hovering attention, the British analyst Nina Coltart has described her style of work as follows:

Bare attention has a sort of purity about it... It's that you simply become better, as

any good analyst knows, at concentrating more and more directly, more purely, on

what's going on in a session. You come to concentrate more and more fully on this

person who's with you here and now, and on what it is they experience with you;

3 The most widely taught exercise in contemporary mindfulness training is the 45-minute sitting meditation carried out silently, in private, by the individual practitioner. While such practice may lead to a sense of inner liberation, it is also possible that practitioners encounter (sometimes severe) psychic difficulties during and after meditation. The American neuroscientist and clinical psychologist Willoughby Britton (Brown University) has done a lot of work in this area, and her Clinical and Affective Neuroscience Laboratory offers, online, open-access research papers on "the varieties of contemplative experience". She has written about the importance of "meditation safety" and has uploaded relevant and useful resources on her website: https://www.brown.edu/research/labs/britton/research/varieties-

contemplative-experience

${ }^{4}$ In an article focusing on psychotherapy with the indigenous peoples of Canada, Blue, Darou \& Ruano (2015) have used this evocative phrase - "Through Silence We Speak" - as the title of their paper.

${ }^{5}$ For a literature review on silence in psychotherapy, see Davies (2007), Lane, Koetting \& Bishop (2002) or Warin (2007). Another good paper is Kurtz (1984), which helpfully discusses inflected and uninflected silence.

Language and Psychoanalysis, 2019, 8 (1), 4-29.

http://dx.doi.org/10.7565/landp.v8i1.1590 
to the point that many sessions become similar to meditations. (Coltart, 1998, p.

176)

Coltart has described such attention as "uncluttered" - she does not say much but holds her thought processes in suspension while closely attending to the patient. The invocation of meditation, without specifically bringing in Buddhist philosophy, is probably what many psychotherapists have been doing for a long time.

In the rest of the paper, I will discuss a number of publications about evenly hovering attention and also about mindfulness, and explore the mutual affinities between the two. While inevitably this will not be an exhaustive review of all the relevant issues, I hope my exploration would provide useful signposts for the interested reader.

\section{Talking and Listening}

Talking is essential to the practice of psychotherapy, but it is not simply a matter of words being uttered. Fundamentally, it is a state of communion between partners in conversation - it constitutes a presence that involves the whole of the participants' being. Bromberg (1994) declares that, in psychoanalysis, speaking is "not simply a process of delivering content. It is also a relational act that shapes the content of what is spoken about" (p. 524). He refers to the imperative attributed to Socrates "Speak! That I may see you!" - as central to psychotherapy. Speaking (and listening) is not information exchange, but a revelation (a presenting) of the self.

Consciousness is always a now experience, a "this-moment" state of mind. Working within the psychotherapeutic frame entails a lingering in the present - to be here, and with this person. Presence is a quality of being felt by the other, of fully inhabiting this now moment, and of showing (presenting) the self. Crucially, it gives time to the partner in conversation: a sense of waiting, respecting the rhythm of what is unfolding, with a tentativeness that offers space, both temporal and imaginative, for the emergence of what is important. Speaking does not have to happen continuously - the silence of waiting, as much as words, is part and parcel of presence.

To be open to novel possibilities in this fully present manner requires a depth of listening that the psychotherapist has to learn to achieve. But listening has become neglected in healthcare environments where the concept of "managed care" has become hegemonic. Graybar \& Leonard (2005) comment that during difficult moments in therapy, it is tempting for all therapists, whether experienced and inexperienced, "to bypass such discomfort by letting go of listening and giving in to the reflex to speak, advise, or lecture" (p. 14).

Graybar and Leonard argue that the ubiquity of drug therapies and the popularity of brief, manualised "empirically-supported treatments" (ESTs) have together subverted the practice of proper listening in mental healthcare. Although the quality of the therapeutic relationship (rather than specific therapy techniques or "ingredients") is 
the best predictor of therapy outcomes, ${ }^{6}$ managers are convinced that quick (programmed), cost-effective (cheap), technique-oriented (manualised) treatments for psychological distress are the only option, in a cultural context where speed and technology trump everything else. While this trend, which has more to do with "business" than "care", is most dominant in the United States, it is clearly gaining traction in the UK.

Within the "managed care" model, the kind of psychotherapeutic listening, where the therapist's own assumptions are suspended, her attention finely tuned to the patient's (unconscious) narrative, and the latter's (sometimes tortuous) revelation accepted with openness, where the patient's experiences count, and where the therapist is not the "boss" but a fellow-traveller, has often been summarily dismissed as unnecessary luxury.

\section{Free Association and Evenly Hovering Attention}

To counter the decline of listening in psychotherapy, it would be instructive to go back to Freud's recommendation of "impartially suspended attention", which he sees as the analytic stance that psychoanalysts should adopt. ${ }^{7}$

Most therapists, even outside of psychoanalysis, know that free association is the fundamental rule for the patient in analysis: she has to say whatever comes to mind without holding back. The other side of the free association coin is evenly hovering attention, which can be characterised as the analyst's free association that enables her to catch the drift of the patient's unconscious. ${ }^{8}$ Thus the freely proffered thoughts,

${ }^{6}$ There is an ongoing debate within the psychotherapy research community regarding the comparative effectiveness of various forms of psychotherapy. One enduring argument is the proposition that "common factors" (or "non-specific factors") underlying all therapies are much more important than modalityspecific elements in producing positive therapeutic outcomes (the "Dodo Bird" verdict). In a 2002 issue of the journal Clinical Psychology: Science and Practice, a number of papers from opposite sides of this debate were helpfully published together (Beutler, 2002; Chambless, 2002; Klein, 2002; Luborsky, 2002; Messer, 2002; Rounsaville \& Carroll. 2002 and Schneider, 2002). Catty (2004) and McAleavey \& Castonguay (2015) have also provided relevant discussions on the debate. Richard Bentall (2009), when commenting on this issue, has concluded that the importance of the quality of the therapeutic relationship is beyond dispute (pp. 244-249).

${ }^{7}$ Freud has used the term gleichschwebende Aufmerksamkeit in his writings (variously translated as "evenly hovering attention", "free-floating attention", "evenly suspended attention", or "impartially suspended attention"), and the most quoted is his 1912 paper on treatment techniques for doctors. Here I am using the 2002 "New Penguin Freud" translation (under the general editorship of Adam Phillips), titled "Advice to Doctors on Psychoanalytic Treatment". (In the Strachey Standard Edition, the title is "Recommendations to Physicians Practising Psycho-Analysis".)

${ }^{8}$ Catching the drift of the patient's unconscious is a phrase Christopher Bollas (1992, 2009) has used to talk about the importance of the analyst's free association in the analytic process.

Language and Psychoanalysis, 2019, 8 (1), 4-29.

http://dx.doi.org/10.7565/landp.v8i1.1590 
gestures, feelings, memories, dreams, questions, tangents, ravings, grimaces, mumblings, etc from the patient are met with a completely open and accepting attitude on the part of the listening analyst. Analysis, in the sense of bringing (interpretative) coherence to the patient's story, takes place when the analyst reflects on the session (or on the whole analysis) afterwards. In Freud's own words, psychoanalytic attention "rejects all aids, even note-taking, and consists simply of not focusing on anything in particular, but giving everything the same kind of 'impartially suspended attention"” (Freud, 1912/2002, p. 33).

Mark Epstein (1984) comments that such attention is not passive or allowing the mind to wander, but "to give 'equal notice' to every object of awareness for hours at a time" (p. 195). In his view, "[e]venly suspended attention has received curiously little attention from the analytic community over the years" (p. 197). But in fact there are a number of early psychoanalysts who have discussed the concept at length or made attempt to develop it further. For example, Wilfred Bion (1967), a British psychoanalyst, has formulated the concept of "without memory and desire" as the analytic listening frame (see next section), and Theodor Reik (1948) has developed the idea of listening with the third ear as an extension of Freud's analytic attention. ${ }^{9}$ The focus of Reik's book Listening with the Third Ear ${ }^{10}$ is to "investigate the unconscious processes of the psychoanalyst himself" (Reik, 1948, p. x). However, Epstein (1984) disagrees with Reik's "searchlight" metaphor. He comments that this metaphor has the connotation of selective attention (searching) which is counter to Freud's evenly hovering attention. To Epstein, Buddhist meditation is closer to what Freud has described.

Another concept, "analytic neutrality" (or the principle of "abstinence"), is also related to the idea of evenly hovering attention. Psychoanalysts have debated about whether neutrality is too passive and therefore off-putting to patients. While cautioning against aloofness, remoteness, blankness and anonymity (likely to be experienced as persecuting), Greenberg (1986) believes that neutrality is "the ideal atmosphere within the context of a particular understanding of the analytic process, one in which self-knowledge is the goal" (p. 81). In this regard, holding evenly hovering attention is an expression of neutrality, and is essential for helping the analysand achieve self-knowledge. However, Greenberg is aware that the analyst adopting a neutral stance does not mean she is not influencing the patient. ${ }^{11}$ Although he acknowledges that the analyst influencing the analytic process is unavoidable, he argues that neutrality (quiet attentiveness) constitutes a beneficial (therefore acceptable) form of influence.

While evenly hovering attention is seen as an attitude expressing openness, receptivity and presence, it is not without its detractors. In Sándor Ferenczi's Clinical Diary, his

${ }^{9}$ Reik's work is not widely discussed nowadays, see Kyle Arnold (2006), Rajan Gupta (2008) or Jeremy Safran (2011) for helpful reviews on Reik.

10 The expression "third ear" is made famous by the $19^{\text {th }}$ Century German philosopher Friedrich Nietzsche's lament about the poor literary quality of books written by his compatriots: "What a torment books written in German are for him who has a third ear" (Nietzsche, 1886/1973, p. 159).

${ }^{11}$ Not influencing the patient's free association or the course/aim of the analysis is a basic principle within the psychoanalytic framework.

Language and Psychoanalysis, 2019, 8 (1), 4-29.

http://dx.doi.org/10.7565/landp.v8i1.1590 
first entry (dated 7 January 1932) contains a strong criticism against the "so-called free-floating attention, which ultimately amounts to no attention at all, and which is certainly inadequate to the highly emotional character of the analysand's communications, often brought out only with the greatest difficulty" (Ferenczi, 1988, p. 1). This was Ferenczi's veiled attack on Freud himself, implying that the latter was an insensitive analyst hiding behind the front of free-floating attention. ${ }^{12}$

Despite Ferenczi's criticism, it should not be impossible for a therapist to hold on to a truly receptive listening attitude with sincere and warm engagement with the patient. Such attention does not have to be a passive attitude that conveys indifference, distancing or boredom. The important thing is how to cultivate an honest openness that sustains genuine relating. The work of Peter Lomas (1981, 1994 and 1999) is a good illustration of sensitive analytic practice.

Looking from another angle, evenly suspended psychoanalytic listening is based on what Reik's has described as "social sense" and "rhythmic sensitivity" which jointly determine "the right moment to communicate an interpretation" (Arnold, 2006, p. 755). The German word Reik has used is Takt which means both "rhythm" and "social tact". To Reik, timing is of crucial importance and he has talked about grasping "the psychological moment" guided by Takt. In listening, the psychotherapist has to be tactful and be able to follow the rhythm of the therapeutic process. In Reik's words, this is listening with the "third ear" - a way of staying in the present, often in silence, and yet closely aligned with psychological time. ${ }^{13}$

The British literary critic James Wood suggests that "novelists and readers must develop their own third ears" and

read musically, testing the precision and rhythm of a sentence, listening for the almost inaudible rustle of historical association clinging to the hems of modern words, attending to patterns, repetitions, echoes, deciding why a metaphor is successful and another is not, judging how the perfect placement of the right verb or adjective seals a sentence with mathematical finality. (Wood, 2008, p. 137-138, emphasis added)

12 The fraught relationship between Freud and Ferenczi (and between Freud and other early analysts such as Jung or Rank) had largely to do with Freud's absolute demand of unquestioning loyalty from his followers. Ever the infallible Father of Psychoanalysis, Freud made it clear that anybody who disagreed with him was unacceptable (in Freud's 2 October 1932 letter to Ferenczi, he accused the latter thus: "you have systematically turned away from me" - quoted in Dupont, 1988, p. xvii).

13 For an exposition on Reik's idea about rhythm and Takt, see Sloma (2010).

Language and Psychoanalysis, 2019, 8 (1), 4-29.

http://dx.doi.org/10.7565/landp.v8i1.1590 
Although Wood is talking about literature, I would suggest that this passage can serve as an apposite description of Reik's "third-ear listening" that should underpin psychotherapeutic practice.

\section{Without Memory and Desire}

Taking Freud's evenly hovering attention seriously, Bion (1967) famously talked about the need to discard memory and desire when starting each and every analytic session. It is Bion's belief that "[p]sychoanalytic 'observation' is concerned neither with what has happened nor with what is going to happen but with what is happening" (Bion, 1967, p. 272). What happens now in the session is the focus, and so "[e]very session attended by the psychoanalyst must have no history and no future" (p. 272). This rule of "without memory and desire" will facilitate the evolution of something significant out of the "darkness and formlessness" of the session. Bion's dictum echoes Freud's view that "if you follow your expectations, you run the risk of never finding out anything you do not know already; if you follow your inclinations, then you are bound to distort whatever you perceive" (Freud, 1912/2002, p. 34).

However, keeping a completely empty mind is impossible. The issue of memory is not a trivial one. In Freud's Advice to Doctors on Psychoanalytic Treatment (1912/2002), he said note-taking should not be carried out during the session (presumably it could be done afterwards); he also cautioned against engaging in "research" or "scientific" work during treatment - such work is only allowed after the completion of the case. The analyst should proceed as if she has no plan/agenda in mind. But is this really feasible?

There are two problems here. Freud's "scientific research" consists only of his case studies, and this work represents his theory-building effort. But how are research data to be collected - simply by the analyst's subsequent recollection? Is the analyst able to trust her ability to retain all the important information without distortion through months (if not years) of therapy? If she does write notes after each session, should she not read them while treatment is ongoing? If the rule is to have no plan (without memory and desire), perhaps the analyst should not write any notes until after the completion of the case? But "completion" probably means the analyst has already arrived at a conclusion or formulation about the patient's problem. As Freud has written up his cases in a way that conforms to his ideas, they are "data" that would inevitably confirm his beliefs. Thus his "research" involves a circularity that is not a rigorous testing of his theory

The other problem is, if the analyst does write notes after each session, and does read them, is it possible to stop hypotheses from forming in her mind during sessions? Is "without memory and desire" humanly possible? If psychoanalysis has made any contribution to human understanding, it is its focus on the unconscious aspect of mental life. ${ }^{14}$ In this regard, the reflexive question is how an analyst could be sure her unconscious has not led her in a particular (perhaps erroneous) direction if she does consult her (subjective) notes before a session.

14 As Otto Kernberg (2014) puts it, “[a] central, unifying concept of all psychoanalytic approaches is the theory of the dynamic unconscious and its influence on conscious life" (p. 11).

Language and Psychoanalysis, 2019, 8 (1), 4-29.

http://dx.doi.org/10.7565/landp.v8i1.1590 
It is important to say here that Bion's stipulation of without memory and desire, like Freud's evenly hovering attention, must not become an excuse for sloppy work. Hooke (no date) usefully suggests that Bion's rule is paradoxical and not literal. It has more to do with the analyst's "complete availability and openness to the patient" (Hooke, n.d., p. 7) rather than abdicating her responsibility to hold things in mind (i.e., to remember).

Both Freud and Bion have remarked that their respective recommendation is distilled from extensive practice. But as Hooke has pointed out, "what happens in the consulting room and what is theorized and gets written is often different" (Hooke, n.d., p. 7). Indeed, reading Freud's cases does not always give the impression of him showing neutrality, openness and receptivity; rather, he always resolutely brings his theory to bear on his patient in the analytic session. ${ }^{15}$ Every psychotherapist has to honestly tackle the risk of her preconceived ideas influencing therapy negatively. In doing so, reflexivity and negative capability are indispensable.

\section{Negative Capability}

While acknowledging the importance of Freud's recommendation, Robert Hobson (1985), a British psychotherapist from the Jungian tradition, has highlighted the importance of negative capability that therapists should cultivate. This is a concept borrowed from the poet John Keats, which signifies the capacity to stay with uncertainties, mysteries and doubts without any "irritable reaching for fact or reason". It is plausible to suggest that such openness is the prerequisite for genuine evenly hovering attention. Negative capability is also what Bion has recommended, not only as a discipline for therapeutic listening, but as the analyst's way of life (Symington \& Symington, 1996, p. 169).

However, negative capability does not mean not working hard. The active nature of evenly hovering attention is clarified in Hobson's (1985) description of how the therapist's attention should be receptive of the "minute particulars" that emerge in the session. Hobson has developed the concept of "aloneness-togetherness" which characterises the clinical encounter as one where the therapist is alone within her own world of reverie but is at the same time together with and responsive to the patient. ${ }^{16}$

In a recent article in the British Psychoanalytic Council newsletter, Kernberg (2014) has sounded a warning:

15 Although Freud has said (as quoted above), "if you follow your inclinations, then you are bound to distort whatever you perceive" (1912/2002, p. 34), he often does not follow his own advice and only sees his patients through the lens of his theory.

${ }^{16}$ Hobson (1985) explains his concept of aloneness-togetherness thus: "to know a person is to be alone and yet together; a personal dialogue both expressing and promoting a relationship of aloneness-togetherness... an apprehension of distinction and of mutuality, of autonomy and of reciprocity, of identity and of sharing" (p. 26).

Language and Psychoanalysis, 2019, 8 (1), 4-29.

http://dx.doi.org/10.7565/landp.v8i1.1590 
There is a naïve assumption that the analyst listening with evenly suspended attention, or with an effort to enter each session 'without memory or desire', open to reverie on the patient's material, will provide the essential and exclusive precondition on which psychoanalytic understanding and interpretation are based. I believe that this assumption is a bias derived from a lack of understanding of what a clear and precise technical approach means. (Kernberg, 2014, p. 11)

What Kernberg is saying here is that maintaining an evenly hovering attention is necessary but not sufficient; there is a need to develop a more sophisticated framework to enhance the disciplined skills-training of analysts. Perhaps one useful framework to consider is Patrick Casement's idea of the "internal supervisor" (see, e.g., Casement, 1985), which has the potential of being adopted by, and adapted for, a range of psychotherapeutic approaches. ${ }^{17}$

\section{A Word about Words}

Freud has used the metaphor of the analyst as a telephone receiver to describe impartially suspended attention (Freud, 1912/2002, p. 37). This has been criticised by a number of analysts. For example, Filip Geerardyn (2002) has pointed out that telephony involves the encoding of an already fixed message, which is then electrically transmitted, and finally decoded by the telephone receiver according to a set of predetermined parameters, whereas in analysis meaning is fluid, not pre-fixed, but emerges in the context of communication, and more than likely emerging differently for the patient and the analyst.

Similarly, Fred Griffin $(2016)^{18}$ rejects Freud's telephone receiver metaphor as too passive, and has stated that "psychoanalytic listening involves acts of sensibility, engagement and imagination" (p. 3). He construes the analytic subject not as hidden inside the analysand's psyche, but as being constantly created, intersubjectively, within the flux of the transference-countertransference matrix. He believes that analysts tend to resort to "content-driven theoretical models" or "impoverished fictions" in times of clinical impasse or confusion, which lead to reductive interpretations. Griffin suggests that analysts should learn from good literature, particularly the novel, where close reading of the "dimensional universes of human experience" offers the practitioner the much needed sensibility training.

The views propounded by Griffin and Geerardyn are more in tune with respect for the unknowability of the human person. To ponder further on Griffin's point about "acts of sensibility, engagement and imagination", it is relevant to consider what the

\footnotetext{
17 Patrick Casement is a British psychoanalyst whose writing has been influential in the broader psychotherapy world, see Casement (1985, 1990, 2002 and 2006).

18 For a helpful review on Griffin's work, see Sybil Ginsburg (2016).
}

Language and Psychoanalysis, 2019, 8 (1), 4-29.

http://dx.doi.org/10.7565/landp.v8i1.1590 
Jungian analyst Barry Proner has said in his aptly titled essay "A word about words". Proner (2006) presents a view that the active task of evenly hovering attention has to do with listening to words, both the patient's and the analyst's own. But it is important to attend to the vicissitude of words: "Words both unite and separate. They can be both symbolic and concrete at the same time" (Proner, 2006, p.432). He believes that patients are looking for words to anchor experiences that are often ineffable or inchoate, and thus "giving a name to the powerful emotional experience that is not yet mentally represented" (p. 430). This is how Griffin has characterised the active nature of evenly hovering attention:

When I am working well and I am in what Freud called 'evenly hovering attention'

and Bion called 'reverie', I can listen most deeply and unconscious meanings are

more accessible. Words can stand out that in another context or at another time

may have no more than ordinary or trivial significance. (Griffin, 2016, p. 426,

emphasis added)

In this context, it is puzzling to find theorists who have interpreted Freud's or Bion's recommendation in rather mystifying ways. For example, the Lacanian analyst Bruce Fink (2007) remarks that evenly hovering attention is "to hear without understanding", without doing anything or imposing any meaning to the "ribbon of sound" produced by the patient (p. 12 and p. 21). One wonders how therapy could proceed on the basis of ribbons of sound? Such negation of words is unhelpful to say the least.

However, there is one thing I would debate with Griffin. In his paper, he has alluded to the importance of finding the "right word". I am not sure if it is possible, or desirable, to be definitive about what the right word is. I would argue it is important always to be tentative: the "right word" might be right one moment, but "not-right" the next. The certainty one achieves today may easily be overturned by what happens tomorrow. Transience or impermanence is a fact of existence. This is the Buddhist insight that psychoanalysis should learn from.

\section{Buddhism and Mindfulness}

In its origin, Buddhism was a philosophy of life rather than a religion. As Safran (2003b) has pointed out, metaphysical and cosmological speculations are irrelevant to Buddhist philosophy. It is not an ontological theory; its aim is to relieve human suffering. The Buddhist idea of impermanence (emptiness or nothingness) is about seeing through the transience and changeability of life, not a metaphysical declaration regarding the origin or essence of existence. Thus Buddhist insights are about how to live. Whether ontologically there is any substance to anything is not of great concern. Existence as such is phenomenologically accepted, and the task is to "get on with it". In this sense, Buddhism does not reject a realist model of the world. Buddhist ethics has to do with accumulating "virtuous conduct", which entails actions (of goodness) in the real, physical world. This forms the basis for moral virtues such as compassion,

Language and Psychoanalysis, 2019, 8 (1), 4-29.

http://dx.doi.org/10.7565/landp.v8i1.1590 
which many contemporary psychotherapists have espoused in their practice, particularly those influenced by Buddhism.

The Buddhist idea of learning to see through the impermanence of all that exists is an important one - it encourages a temperament that is not fixated on "Truth". This is what psychoanalysis should embrace: it is not a matter of the truth of analytic interpretations that is important, it is their usefulness (or otherwise) in helping the patient live a good life that counts. ${ }^{19}$ Thus, psychoanalysis is an ethical practice, not a "scientific" one as narrowly conceived. In German (Freud's working language), the word for "science" (Wissenschaft) is the same as that for "knowledge", with a much wider range of meaning. The Latin root of "science" is to know ("scientia"), which is far from the mechanistic, laboratory connotations that the word conjures up in many people's mind in the English-speaking world. An ethical practice has to be based on how and what we know about the world (based on "science"), even if such knowledge is incomplete, approximate, tentative or even defective. It is in this wider context of "science" that psychoanalysis might converge with Buddhism.

Understood as a practical philosophy, the conundrums within Buddhist thinking the idea of "no-self-ness", "emptiness", or the world as illusory - are easier to grasp. Quoting the well-know declaration of Harvard psychotherapist Jack Engler, the Slovenian analyst Borut Škodlar (2016) said "you have to be somebody before you can be nobody" (p. 128). This is one way of resolving the paradox of "no-self-ness". Even though the world is concretely there and suffering is real, we can, and have to, live as if they are but empty. This is what Buddha believes to be the basis for transcending suffering. To be "somebody but also nobody" does not remove the person from participating in the world. Zen teaching is particularly this-worldly and is not trapped in any ontological maze. I believe it is Zen that would most benefit the practice of psychotherapy. ${ }^{20}$

Most readers know that mindfulness practice is a discipline of staying with the present, dwelling in silence, and paying attention to all that there is with curiosity and an open and non-judgemental attitude. The rhythm of breathing is used as an anchor to help the practitioner stay with now and let go of thinking. Simply noticing and accepting (even of the practitioner's own wandering mind) is all that is required. This description, though cursory, already suggests an affinity between mindfulness and Freud's evenly hovering attention or Bion's no-memory-no-desire reverie.

Like psychoanalysts, mindfulness practitioners place great emphasis on the idea of neutrality, albeit with a different nuance. In meditation, being neutral and detached means the practice is not about success or failure, or striving to achieve anything, but simply staying with a moment-by-moment awareness. There is no duality of body and

19 The Chicago philosopher and psychoanalyst Jonathan Lear has made a strong case for the view that the practice of psychoanalysis is about how to live a good life (see Lear 1998, 2004, 2014).

20 Zen is much more than just meditation, even though the Chinese word for Zen (禪) does mean meditation. The practice of Kōan (stories or riddles that have no logical solution) as a way of grasping the paradoxical nature of the human condition, is part and parcel of Zen.

Language and Psychoanalysis, 2019, 8 (1), 4-29.

http://dx.doi.org/10.7565/landp.v8i1.1590 
mind (e.g., the physical practice of archery is also a practice of the mind); and no duality between the mind and the world ( $I$ am the arrow). As such, mindfulness becomes second nature: as the stream of my consciousness, as my being. This experience of "now" is an indwelling in the world unique to human subjectivity. ${ }^{21}$ There are many questions about mindfulness practice still being debated. Is it possible to be "just noticing" and nothing else? What does noticing mean anyway? Isn't noticing a form of thinking? But isn't there an understanding of meditation as "notthinking"? How can this paradox be resolved? Is it possible to achieve a completely uncluttered mind? Can we ever suspend judgement totally, or is it not the case that being conscious means making judgement (moral or otherwise) all the time? These questions can also be directed at the psychoanalytic idea of no-memory-no-desire or evenly hovering attention. They reflect a commonality between the two.

Furthermore, there is a paradox about the non-striving attitude of mindfulness: if we stop striving altogether, what does disciplined meditative practice entail? Doesn't such practice require effort - a form of striving towards an end? Another paradox: Is mindfulness a language-based practice? Think of what mindfulness teachers are doing when leading a meditative exercise - words are used to capture and hold the attention of the practitioners. Would these words trap the mind, thus negating the idea of emptying the mind? These questions are not raised to reject mindfulness, but to widen the horizon for exploration.

It is important to say that neither Buddhism nor mindfulness practice is anti-rational. As the Bodhidharma has said, "Many roads lead to the Path, but basically there are only two: reason and practice" (Bodhidharma, 1987, p. 3). Both reason and practice are part of the Buddhist discipline of life: "Buddha means awareness, the awareness of body and mind that prevent evil from arising in either. And to invoke means to call to mind, to call constantly to mind the rules of discipline and to follow them with all your might" (Bodhidharma, 1987, p. 111). On this basis, it is not unreasonable to say that mindfulness does involve subjectivity (the phenomenal experience of the "I") in the context of striving in a particular direction ("invoking rules of discipline").

What mindfulness can learn from psychoanalysis is the acknowledgement of the unconscious - that the mind has a depth which is more than we are able to fathom. ${ }^{22}$ The significance of the unconscious dimension of human experience cannot be ignored. To that extent, to empty the mind is not a task that can ever be achieved, and mindful attentiveness is never an act always under the conscious control of the person. Such understanding may help to alleviate a practitioner's sense of failure of not achieving complete blankness of the mind. More importantly, such acknowledgement may also help the mindfulness community learn to tackle some of the meditationrelated (sometimes severe) psychic or emotional difficulties that practitioners might encounter.

21 The understanding of mindfulness as an experiential me-in-the-world perspective is rarely commented on; this aspect of mindfulness has, in my view, a strong affinity with the philosophical tradition of phenomenology in terms of the concept of intentionality.

22 Of course the notion of the "mind" is a contested one. I am using it as shorthand for how we experience phenomenal subjectivity (the sense of "I") (See Li, 2018).

Language and Psychoanalysis, 2019, 8 (1), 4-29.

http://dx.doi.org/10.7565/landp.v8i1.1590 
One danger, as I see it, is that mindfulness has not only become a popular therapy modality, but also a burgeoning enterprise that has entered into mainstream society, in healthcare, schools, public institutions or the business and management world, almost as a panacea for all ills (e.g., see Crane 2017). It is important to see mindfulness as a reflexive and reflective way of life rather than a technique. When something becomes a therapy technology or a brand of merchandise, and is packaged and put on sale, there is a high probability that it would become corrupted. ${ }^{23}$

The interest psychoanalysts have shown toward Buddhism or meditation is not new. There is a considerable literature which this paper will not have space to address, ranging from Carl Jung's or Erich Fromm's well-known texts (Jung, 1978; Suzuki, Fromm \& de Martino, 1960), to more recent studies by various analysts (e.g., Falkenström, 2003; Leone, 1995; Lin \& Seiden, 2014; Mace, 2008; Makise, 2017; Moncayo, 2012; Safran, 2003a; Suler, 1995; Young-Eisendrath \& Muramoto 2002). Some of these works are not particularly helpful, such as Makise (2017) or Moncayo (2012), with inaccessible theoretical baggage couched in esoteric (Lacanian) language.

In the cognitive-behaviour therapy tradition (CBT), mindfulness has also had great impact, as can be seen in publications ranging from the popular text MindfulnessBased Cognitive Therapy for Depression (Segal, Williams \& Teasdale, 2002), to Compassion-Focussed Therapy (e.g., Gilbert, 2009), Dialectical Behaviour Therapy (e.g., Linehan, 1993), or Acceptance and Commitment Therapy (e.g., Hayes, 2002; Hayes et al., 2006). Of course mindfulness has attracted other therapists as well, including the somatic or body-oriented psychotherapies (e.g., Weiss, 2009) and Emotion-Focused Therapy (Geller \& Greenberg, 2012).

In this context, Škodlar's question is of interest: "Where in the landscape of psychotherapy would be an appropriate place for mindfulness? Is cognitive-behavior therapy (CBT) really the most suitable area within which to locate a mindfulnessoriented approach?" (Škodlar, 2016, p. 126).

Škodlar's answer is that mindfulness has the most affinity with existentialist or phenomenological psychotherapy. He says, "one cannot think of many more suitable adjectives to add to mindfulness than existential, and it is certainly more appropriate than cognitive, analytic or systemic" (Škodlar, 2016, p. 128). That, unfortunately, runs the risk of turning mindfulness into a specific brand rather than acknowledging it as the fundamental attitude (or way of being) that all psychotherapists should cultivate.

\section{The Tango of Psychoanalysis with Mindfulness}

One area of discussion, in terms of the rapprochement between psychoanalysis and mindfulness, is the question of what the "self" is and how Buddhism and psychoanalysis converge or diverge in this respect (see, e.g., Falkenström, 2003 or Sular, 1995). Usually the attempt is to postulate various structures of the self (core self, self-structure, selfobject, the observing self, etc), and compare and contrast how Buddhist ideas and psychoanalytic theories might come together in this respect.

${ }^{23}$ One useful review of the ethical problems the burgeoning mindfulness movement faces is Harrington \& Dunne (2015).

Language and Psychoanalysis, 2019, 8 (1), 4-29.

http://dx.doi.org/10.7565/landp.v8i1.1590 
However, such discussion often gets lost in a theoretical labyrinth that is not helpful to practitioners. Falkenström's (2003) attempt to resolve the contradiction between the psychoanalytic concept of self and the Buddhist idea of "no-self-ness" fails because, in my view, a structural model of the self does not do justice to lived experience. To me, the "self" is a way of speaking about the experiencing of subjectivity - it is in the practical living in and amongst people, in interactions and mutual interrogations that the self becomes meaningful. To think of the self in terms of the contents of the mind (mental representations, hierarchical differentiation within the self-system, etc) reifies the dynamic, phenomenal experiencing of being a (material) subject.

Theorising about the self as a system of mental representations, like what Falkenström has done, does not chime with the Buddhist sense of "no-self-ness", which is pointing to the ineffable, non-structural nature of subjectivity. While Falkenström has expressed doubt about the concept of the "self", he still gets muddled in trying to explain his idea. Just take one of his propositions: "When the individual has identified with part of experience as 'self', there will inevitably be threats to this self..." (Falkenström, 2003, p. 9). One wonders who (or what) the "individual" is, and whether this "individual" already exists prior to, and separately from the "self" that appears later on in the sentence. Or perhaps Falkenström is saying that "experience" constitutes (becomes) the self which the individual then identifies with? But does this dualism make sense?

Many psychoanalysts are more concerned about the therapeutic aspects of mindfulness than theories about the self. Kathleen Speeth (1982) discusses the importance for the psychotherapist to maintain both focused and panoramic attention "in both direction" (i.e., to herself and to the other person), and refers to meditation techniques of various Eastern traditions, including Zen practice. In her view, Freud's evenly hovering attention represents panoramic attention, which resonates with mindfulness. She has also coined the phrase "witness consciousness" (p. 155) similar to Casement's (1985) "internal supervisor" - which could be construed as meta-level observation essential for keeping a detached view of the therapeutic process.

While many therapists have espoused mindfulness practice as therapy tool, some go further and commit themselves to a Buddhist way of life - the late Jeremy Safran, a widely respected Canadian-born but New York-based psychoanalyst was one of them. ${ }^{24}$ In reviewing Safran's 2012 text Psychoanalysis and Psychoanalytic Therapies, British psychotherapist Jeremy Holmes remarks on the importance of Safran's commitment to Buddhism:

$[\mathrm{T}]$ he book is permeated by Safran's Buddhist background. He discusses the tension between the meliorist American dream of unlimited possibility of psychic

${ }^{24}$ Clinical psychologist and relational psychoanalyst Jeremy Safran has produced important work about the dialogue between Buddhism and psychoanalysis (e.g., Safran, 2003a). His recent tragic death is a great loss to psychotherapy - see https://tricycle.org/trikedaily/remembering-buddhist-psychoanalyst-jeremysafran/

Language and Psychoanalysis, 2019, 8 (1), 4-29.

http://dx.doi.org/10.7565/landp.v8i1.1590 
change and unbounded optimism, with Freud's rational pessimism and stoicism.

From a Buddhist perspective, the paradox is that the more one can come to accept oneself and the world as it is, the more one is in a position to change both. (Holmes, 2013, p. 103)

Pessimism and stoicism are seen here as conducive to the development of resilience, and this echoes what Lin \& Seiden (2014) say about psychoanalysis and Buddhist mindfulness philosophy as "the turning toward distress rather than turning away from it" (p. 4). That is, both perspectives are regarded as being honest in their acceptance of the reality of suffering in the world. The Buddhist practice of "no-self-ness" is what analysts like Safran believe to be an effective means for coping with inevitable suffering. This is not a denial of existence, but a way of grasping its transience. As van Waning (2002) has said: "The Buddha did not say, 'You don't exist,' but rather, 'You have no self.' His point was not to deny or reject the self, but to recognize the self-representation as representation, as a concept without existence of its own". (p. 93)

To embrace the paradox of transience, it would be incumbent on us to acknowledge that we know, and yet we know we don't know. This is radical openness (similar to negative capability discussed above). It is a paradoxicality that sets us free. To quote Safran:

In Buddhist constructivism, the primary thrust is to cultivate a radical sense of openness. The belief is that concepts enslave us and that the tendency toward reification creates suffering. The emphasis is not on constructing adaptive narratives but rather on the radical deconstruction of all narratives. It is interesting to note that this emphasis on radical openness is similar in some respects to the growing awareness in analytic thinking of the importance of the analyst's openness and tolerance of ambiguity. (Safran, 2003b, p. 22)

Perhaps Freud was enslaved by his craving to be right, and this had blinkered him. Within the Buddhist perspective, craving is the source of suffering as it leads to illusions. What psychoanalysts can learn from Buddhism or mindfulness practice is, as Safran has suggested, to give up such craving and embrace radical openness. Letting go of concepts that shackle intelligence, theories that diminish horizon and fixed self-identifies that restrict imagination may yet provide psychoanalysis with an opportunity for renewal. Embracing impermanence and emptiness - this will be psychoanalysis in a mindfulness frame. 


\section{Mindfulness, Psychoanalysis and Mentalisation}

It is not uncommon to find inexperienced therapists confusing mindfulness with mentalisation. The latter is a relatively recent development within the psychodynamic tradition, originally with a specific focus on working with people struggling with borderline personality difficulties. Anthony Bateman and Peter Fonagy (2004, 2006), two London-based psychoanalytically trained psychotherapists, have pioneered this approach. At the beginning, Bateman and Fonagy said mentalisation is "a focus for therapy rather than a specific therapy in itself" (2006, p.159) - it is what all good therapy should be like. Sadly, like much else in the psychotherapy world, mentalisation has now become packaged and widely advertised in the therapy "market-place".

This is not an appropriate place to go into a lengthy exposition of the mentalisation perspective; suffice it to say it is a therapeutic framework based on the concept of "mind-mindedness". Or, to put it simply, it is a style of working that constantly attends to what is happening in a person's mind. ${ }^{25}$ The therapist is not only focusing on understanding the thinking, reasoning or feeling of the patient, but most importantly, on how the latter attributes motives or intention to other people's actions. Furthermore, the therapist is trying to foster the same reflective capacity in the patient so that the latter can gradually learn to grasp the mind of others (hence "mindmindedness").

Thus mentalisation is about "keeping mind in mind" (own mind and others' minds), not making up the mind too quickly (keeping an open mind or "not knowing" stance), and being curious about the mind, in order to understand what is going on in one's own mind and in the minds of other people. To be able to mentalise is to be able to use language effectively: to move from the concrete (language as literal representation) to the symbolic (language as metaphorical), thus moving from (impulsive, physical) action to (discursive) articulation, i.e., to be able to talk (e.g., about a problem) rather than act blindly (e.g., hitting out to solve a dispute). Mentalisation is about intersubjectivity, about relating to another person as a thinking and speaking subject. Although it is not a form of psychoanalysis, mentalisation does have roots in the analytic tradition. The capacity for mentalising is likely to help sustain an analyst's evenly hovering attention.

Inspired by the seminal work of Hans Loewald (1960), Jonathan Lear (2003) has written an essay about "objectivity" 26 , by which he does not mean the kind of positivist, reductionistic, "the world is what it is" realism that places unquestioning faith on quantitative measurements. Rather, he talks about the "subjective sense of objectivity" (Lear, 2003, p. 49) which entails a recognition that the world is made up of other subjects whose subjectivity one has to reckon with and try to understand (although they seem like "objects" out there). Such acknowledgement of intersubjectivity constitutes true objectivity, as Lear understands it. To me, the idea of the "subjective sense of objectivity" is another way of describing a person's capacity for mentalisation.

\footnotetext{
${ }^{25}$ Conceptually, it is similar to the idea of "theory of mind" in the field of autistic spectrum disorder studies.

${ }^{26}$ Chapter 2 "Subjectivity, Objectivity, and Irony" in Lear (2003).
}

Language and Psychoanalysis, 2019, 8 (1), 4-29.

http://dx.doi.org/10.7565/landp.v8i1.1590 
There are important differences between mindfulness and mentalisation - emptying the mind $v s$ knowing the mind; detachment $v s$ balanced attachment; absence of goals vs relationality and intentionality - but they do share similar concerns. Presence is indispensable to both; and both are respectful of and curious about the mind. Falkenström (2012) has made an attempt to bring mindfulness, mentalisation and psychological mindedness under the rubric of self-observation. This highlights the subjective grasp of phenomenal experiencing as central to both mindfulness and mentalisation (despite the paradoxical Buddhist idea of "no-self-ness").

While acknowledging the differences between mentalisation and mindfulness, Chris Mace (2008) has commented on the advantage of bringing them together:

$[\mathrm{M}]$ entalization, a capacity that enhances what Fonagy has termed 'reflective self function' through an articulated appreciation of minds (our own and those of others) as the locus of personal history, affect, thought and action, is quite orthogonal to the pre-reflective capacity that is mindful awareness. In practice, development of the two functions can be therapeutically synergistic" (p. 126).

The idea of synergy suggested by Mace points to the possibility of alliance that would benefit both. However, it is important to bear in mind that mindfulness and mentalisation are not so much theory as practice. Any theorising of either must be a reflection of the experience of mindfulness or mentalisation in reflexive practice, where the process, rather than content, is the focus.

\section{Performativity}

Psychoanalysis, mindfulness and mentalisation share the commonality of openness towards the phenomenal experience of subjectivity (the "I" experience). At its best, such openness signifies an honest seeking of understanding of subjectivity, notwithstanding the fact that full understanding is impossible. In this regard, the practice of subjectivity could be profitably explored in terms of the concept of performativity.

Witness a mindfulness teacher in action: he shows the earnestness of an evangelical preacher, with beguiling intonation, inflection of voice, and subtle or not so subtle gestures, even the expression in his face (albeit with eyes closed) - coaxing the participants to follow the meditative exercise. Knowingly or unknowingly, he is performing to an audience, even though most of the participants have kept their eyes shut.

Nowadays, most therapists are keen to point out that they have embraced mindfulness not as religion (Buddhism), but as a mental discipline beneficial to therapy work. Nevertheless, there is often a touch of liturgy in the gatherings of mindfulness practitioners, such as beginning and ending with group meditative practice, not dissimilar to prayers in a religious meeting, even if the mindfulness event is a research

Language and Psychoanalysis, 2019, 8 (1), 4-29. 
or academic seminar. I bring this up not as criticism, but to highlight performativity within the "mindfulness community".

While performativity is a modern concept, the phenomenon it seeks to describe is not new. The performative has always been an important element of the cultural history of the human species, most noticeably in religious practices and the dramatic art. In the contemporary art scene, performance art is becoming a highly visible practice. ${ }^{27}$ According to Fischer-Lichte (2004/2008), one major aspect of the performative can be described as how to do things with words. (The emphasis here is "to do things".) Two important qualities of the performative are embodiment of the dramatic ("materializing of possibilities") and independence from pre-existing categories or essence (the "non-referential" nature of performative acts). As such, the performative is "of crucial importance in constituting bodily as well as social identity" (FischerLichte, 2004/2008, p. 27). Religious rituals or liturgies are performative in that they constitute identities and realities. ${ }^{28}$ The practice of mindfulness, like prayers, can be performed publicly or in private. In both situations, it is constitutive of the identity of the practitioner(s).

Drawing from Shakespeare's work, Cox and Theilgaard (1987) suggest that silence in psychotherapy is not always evidence of resistance, as it is a recurrent feature in the unfolding of the human story within therapeutic space, and the precise meaning of the silence "only emerges in performance" (p. $3-4)$. In this regard, the reticence of the analyst can be seen as part and parcel of a performative set-up. Freud has indicated that he "cannot bear to be stared at for eight hours a day or longer" (Freud, $1913 / 2002$, p. 55) and has laid down a rule about the analyst sitting behind the patient (who is lying on the couch). ${ }^{29}$ This requirement has then become theoretically justified. Such a seating arrangement resembles the director sitting behind the camera, controlling the performance of the actors and film crew.

It is possible to view free association as the performance the analysand has to deliver: a creative and improvised act, through which a narrative, even if incoherent, emerges. However, no matter how "free" the patient's associations seem to be, they are of necessity contextual, motivated, sometimes rhetorical, always for a purpose, with or without the patient's awareness. It is often the case that patients conform to the analyst's theory when "performing" free association, as if following the analyst's (invisible) script. This is not to say the patient's account is fictitious. Its performativity resides in the quasi-liturgical function it fulfils, whether seen as Catholic confessional or other forms of religious/dramatic catharsis. This performativity is crucial in constituting the analysand within the analytic frame.

To think about psychoanalysis and mindfulness as performative does not detract from their therapeutic possibilities. Rituals, religious or otherwise, are essential for the reenchantment of subjectivity (the "I" experience) and of the world, as they are

27 See, e.g., Marina Abramović's work: https://mai.art

${ }^{28}$ For example, the Eucharist (the "Lord's Supper") is, in Catholicism, a performative act that becomes the literal reality of Christ's body and blood (the doctrine of transubstantiation).

${ }^{29}$ Freud explicitly said this was his "personal motive" for using the couch - but the personal whim of the founding father has escaped analysis.

Language and Psychoanalysis, 2019, 8 (1), 4-29.

http://dx.doi.org/10.7565/landp.v8i1.1590 
generative of meanings and identities. Rituals can be curative, even if their truth-value is impossible to ascertain.

\section{Freud's Performative Act}

If performativity constitutes identity, there is no doubt that Freud's status as the infallible Founding Father of psychoanalysis is underpinned by his performative act.

"Long experience had taught me, as it might anyone else..." (Freud, 2002, p. 3); "Experience tells us..." (p. 24); "Analysis has shown..." (p. 26); "Experience has taught us..." (p. 173). You can almost see Freud say all this with a flourish - his waving of the hand confirming the truth of what he is going to say. His way of talking (and writing) undergirds the truth of his ideas, the basis of which lies in what he himself has done and experienced. His performative act is declarative. It is the performativity of Freud's work that has generated the whole edifice of psychoanalysis.

In the words of Adam Phillips:

Freud was always puzzled about what he was writing about when he was writing about psychoanalysis. His writing - in which he can be so apparently lucid and fair in describing the obscurity and the derangement of what he calls the unconscious - is a performing of this puzzle. There is far more speculation and conjecture in his writing, more theory-making and story-telling, than instruction or even guidelines about the actual practice of psychoanalysis (and his case histories are nothing if not tributes to the cult of his personality; they are not easily replicable or imitable experiments). (Phillips, 2002, p. x, emphasis added)

It is the story-telling nature of Freud's work that is so interesting, particularly from the vantage point of performativity, even though, as Phillips has pointed out in the above passage, Freud's performative act sometimes reflects his own contradiction. Of course Freud's patients are not his fictional invention; the point is, the psychological world in which Freud has situated his patients is very much his creation. His (written) cases always develop in such a way as to confirm his theories, even if the therapy itself fails to cure the patient.

Adam Phillips has suggested that: "If Freud had died, at the age of forty-nine, having completed these five books, ${ }^{30}$ psychoanalysis would have been very different, but it

30 The five books are: The Interpretation of Dreams (1900), The Psychopathology of Everyday Life (1904), Three Essays on the Theory of Sexuality (1905), Jokes and Language and Psychoanalysis, 2019, 8 (1), 4-29. 
would have been sufficiently complete" (Phillips 2014, p. 145). He does not think Freud's later work (structural theory of the mind, concept of death drive, or writings on religion and cultural issues) is important to the essence of psychoanalysis. The "early Freud" is risk-taking, speculative, bold and more open to possibilities, whereas the established Freud has become a structure, a grand theory, an institution (in both senses of the word). If he had died in 1905/1906, there might not be a psychoanalytic empire or a founding deity. To me, the "mature" Freud has taken on a different performativity, one which has restricted the horizon of psychoanalysis. In this context, it is plausible to suggest that both the performative and the improvisational could, if practised with an open mind, extend the horizon and bring the imaginative to bear on the ordinary, thus generating realms of meanings hitherto unexplored.

The challenge is how not to turn Freud into a god. Psychoanalysis can be radical, as Safran has remarked:

We have seen how both Buddhism and psychoanalysis have struggled over time with the tension between the poles of agnosticism or atheism versus faith and commitment. Within psychoanalysis the tendency to deify Freud and to treat his words as gospel can be seen as another form of the return of the repressed. (Safran, 2003b, p. 21)

\section{Identity and Performativity}

According to Jonathan Lear, the commitment to becoming a psychoanalyst is a foundational performative act:

"[A]s psychoanalysts, we are constantly in the process of shaping ourselves as psychoanalysts... We strive to shape ourselves into people who can listen well...

This is a process of becoming a certain kind of a person... Being a psychoanalyst is in part a never-ending task of bringing oneself back to the activity of being a psychoanalyst... To put it paradoxically: to be an analyst one must ever be in the process of becoming an analyst. (Lear, 2003, p. 32)

To Lear, the commitment of an analyst to psychoanalysis must be total - it is not a one-off exercise limited in scope and in time; instead, it should permeate the whole of the analyst's life. As Lear sees it, however, to be a psychoanalyst is not a matter of

their Relation to the Unconscious (1905), and Fragment of an Analysis of a Case of Hysteria (Dora) (1905).

Language and Psychoanalysis, 2019, 8 (1), 4-29.

http://dx.doi.org/10.7565/landp.v8i1.1590 
following Freud (or any of the other early analysts), ${ }^{31}$ or of choosing a career; it is a specific project of being/becoming a person, and thus a life-long moral practice. Similarly, Bion has suggested that negative capability should become a way of life for the analyst, and mindfulness teachers always say, unequivocally, that meditation is not a therapy technique but an indwelling in a particular form of being. Here, no doubt, is where psychoanalysis and mindfulness converge.

\section{Concluding Remarks}

Words and silence are both essential to psychotherapy, as they embody the performative in the intersubjective world of the therapeutic space. As Cox and Theilgaard (1987) have said, psychotherapy is concerned with "the significance of the changing eloquence of silence" (p.3), and, I would add, with the vicissitude of words. How a psychotherapist manages to balance between silences and words is a continuing learning process. While bearing in mind all the caveats discussed in this essay, it is perhaps not unreasonable to say that "evenly suspended attention", within a mindfulness frame and maintaining full respect towards "other minds" - or, the mindfulness stance with a deep awareness of the unconscious dimension of subjectivity - constitutes a crucial starting point in this learning process. It is, ultimately, a matter of learning to listen, and learning to speak from listening.

A human story "performed" within therapeutic space always starts from an arbitrary point in time. The story often goes round in circles and criss-crosses different worlds in a zigzagging, meandering way, getting entangled with seemingly irrelevant details and detours, sometimes in a direction that may surprise one or both participants. There is a lot of to-ing and fro-ing, of mixing and blending, of veering on a tangent, but the repeated play is not repetitive, as consciousness is never linear or neat and tidy, but full of random and messy bits and pieces, repetitions, diversions and cul-desacs. When all the strands eventually come together - if they do come together (as they might not) - the experience may be like what T. S. Eliot has famously said, We shall not cease from exploration/And the end of all our exploring/Will be to arrive where we started/And know the place for the first time. ${ }^{32}$

Rowan Williams, former Archbishop of Canterbury, was in New York on 11th September 2001, a few streets away from the World Trade Centre. He was in a church meeting when the world was shattered by the unimaginably brutal terrorist acts perpetrated on the twin towers. In 2002, he published a pamphlet, just over 80 pocketsized pages long, of his reflections on the cataclysmic event of $9 / 11$. In this piece of writing, Williams talks about his experience of an "empty space":

In that time, there is no possibility of thinking, of explanations, of resolutions. I

can't remember much sense of panic, much feeling about the agony going on a

31 This is how Lear (2014) puts it: “... if psychoanalysis is to live up to its promise of being a moral psychology - one which contributes as it comes to understand what it is to lead a full, rich, meaningful human life - it must find ways to mourn Freud's legacy, and move on." (p. 480).

${ }^{32}$ From T. S. Eliot's 1942 poem Little Gidding, in Quartet No 4 of Four Quartets, Faber \& Faber 2001 paperback edition

Language and Psychoanalysis, 2019, 8 (1), 4-29.

http://dx.doi.org/10.7565/landp.v8i1.1590 
couple of hundred yards away, let alone much desire for justice or vengeance. It was an empty space.... But somehow the emptiness 'resources' us. (Williams, 2002, p. 10-11, emphasis added) ${ }^{33}$

Of course the terror of $9 / 11$ is of a different order compared to the pain and suffering of patients that most psychotherapists encounter in their day-to-day work. Nevertheless, the "empty space" (silence and stillness) that Williams has described resonates with both the psychoanalytic silence of evenly hovering attention as well as the fully present awareness of the mindfulness perspective. It is in such silence and stillness that true listening occurs. And then words of healing might return.

\section{Authors' Biographical Note}

Chin Li was formerly consultant clinical psychologist with Greater Glasgow \& Clyde Health Board in Scotland and psychology professional lead for Renfrewshire \& Inverclyde Sector. He retired from the NHS in 2015, and is now devoting his time to writing.

\section{Acknowledgment}

I am grateful to the three anonymous reviewers who have made very helpful suggestions on the first draft of this essay. I would also like to thank the Editor of this journal for her advice on the revision of the paper.

\section{References}

Arnold, K. (2006). Reik's theory of psychoanalytic listening. Psychoanalytic Psychology, 23, 754-765.

Bateman, A., \& Fonagy, P. (2004). Psychotherapy for borderline personality disorder: Mentalization-based treatment. Oxford, UK: Oxford University Press.

Bateman, A., \& Fonagy, P. (2006). Mentalization-based treatment for borderline personality disorder: A practical guide. Oxford, UK: Oxford University Press.

Bentall, R. P. (2009). Doctoring the mind: Why psychiatric treatments fail. London, UK: Allen Lane (2009)

Beutler, L. E. (2002). The Dodo bird is extinct. Clinical Psychology: Science and Practice, 9, 30-34.

Bion, W. R. (1967). Notes on memory and desire. The Psychoanalytic Forum, 2, 272273.

Blue, A. W., Darou, W. G., \& Ruano, C. (2015). Through silence we speak: Approaches to counselling and psychotherapy with Canadian First Nation clients. Online Readings in Psychology and Culture, 10. Retrieved from https://doi.org/10.9707/2307-0919.1095

Bodhidharma (1987). The Zen teaching of Bodhidharma. Port Townsend, WA: Empty Bowl.

33 I have written elsewhere about how the work of Rowan Williams has influenced my thinking about psychotherapy, see Li (2010).

Language and Psychoanalysis, 2019, 8 (1), 4-29.

http://dx.doi.org/10.7565/landp.v8i1.1590 
Bollas, C. (1992). Being a character: Psychoanalysis and self experience. London, UK: Routledge.

Bollas, C. (2009). The infinite question. Hove, UK: Routledge.

Bromberg, P. M. (1994). "Speak! That I may see you!": Some reflections on dissociation, reality, and psychoanalytic listening. Psychoanalytic Dialogues, 4 , 517-547.

Casement, P. (1985). On learning from the patient. London, UK: Tavistock.

Casement, P. (1990). Further learning from the patient: The analytic space and process. London, UK: Routledge.

Casement, P. (2002). Learning from our mistakes: Beyond dogma in psychoanalysis and psychotherapy. Hove, UK: Brunner-Routledge.

Casement, P. (2006). Learning from life: Becoming a psychoanalyst. Hove, UK: Routledge.

Catty, J. (2004). 'The vehicle of success': Theoretical and empirical perspectives on the therapeutic alliance in psychotherapy and psychiatry. Psychology and Psychotherapy: Theory, Research and Practice, 77, 255-272.

Chambless, D. L. (2002). Beware the Dodo bird: The dangers of overgeneralization. Clinical Psychology: Science and Practice 9, 13-16.

Coltart, N. (1998) Slouching towards Buddhism: in conversation with Anthony Molino. In A. Molino (Ed.), The Couch and the Tree (pp. 176-193). New York, NY: North Point Press.

Cox, M., \& Theilgaard, A. (1987). Mutative metaphors in psychotherapy: The Aeolian Mode. London, UK: Tavistock.

Crane, R. S. (2017). Implementing mindfulness in the mainstream: Making the path by walking it. Mindfulness, $8,585-594$.

Davies, A. (2007). Contemplating Silence: A review of understandings and clinical handling of patient silence in psychoanalytic psychotherapy. Unpublished dissertation, Auckland University of Technology, New Zealand. Retrieved from https://core.ac.uk/download/pdf/56361462.pdf

Dupont, J. (1988). Introduction. In S. Ferenczi (edited by J. Dupont). The clinical diary of Sándor Ferenczi (pp. xi-xxvii). Cambridge, MA: Harvard University Press.

Epstein, M. D. (1984). On the neglect of evenly suspended attention. The Journal of Transpersonal Psychology, 16, 193-205.

Falkenström, F. (2003). A Buddhist contribution to the psychoanalytic psychology of Self. The International Journal Psychoanalysis, 84, 1551-1568.

Falkenström, F. (2012). The Capacity for Self-Observation in Psychotherapy. Unpublished dissertation, Linköping University, Sweden.

Ferenczi, S. (1988). The clinical diary of Sándor Ferenczi (edited by J. Dupont and translated by M. Balint \& N. Z. Jackson). Cambridge, MA: Harvard University Press.

Fink, B. (2007). Fundamentals of psychoanalytic technique: A Lacanian approach for practitioners. New York, NY: Norton \& Co.

Fischer-Lichte, E. (2004/2008). The transformative of performance: A new aesthetics. Abingdon, UK: Routledge.

Freud, S. (2002). Advice to doctors on psychoanalytic In Sigmund Freud: Wild analysis (pp. 31-41). London, UK: Penguin Books. (Original work 1912)

Freud, S. (2002). On initiating treatment. In Sigmund Freud: Wild analysis (pp. 3141) London, UK: Penguin Books. (original work published 1913)

Language and Psychoanalysis, 2019, 8 (1), 4-29.

http://dx.doi.org/10.7565/landp.v8i1.1590 
Freud, S. (1985). The complete letters of Sigmund Freud to Wilhelm Fliess 18871904. Cambridge, MA: Harvard University Press.

Freud, S. (2002). Sigmund Freud: Wild analysis. London, UK: Penguin Books.

Geerardyn, F. (2002). Unconscious communication and the resistance of the psychoanalyst. Psychoanalytische Perspectieven, 20, 591-601.

Geller, S. M., \& Greenberg, L. S. (2012). Therapeutic presence: A mindful to effective therapy. Washington, DC: American Psychological Association.

Gilbert, P. (2009). The compassionate mind. London, UK: Constable.

Ginsburg, S. A. (2017). Book review of Creative listening and the psychoanalytic process: Sensibility, engagement and envisioning by F. L. Griffin. The Psychoanalytic Quarterly, LXXXVI, Number 3, 731-737.

Graybar, S. R., \& Leonard, L. M. (2005). In defense of listening. American Journal of Psychotherapy, 59, 1-18.

Greenberg, J. R. (1986). The problem of analytic neutrality. Contemporary Psychoanalysis, 22, 76-86.

Griffin, F. L. (2016). Creative listening and the psychoanalytic process: Sensibility, engagement and envisioning. Abington, UK: Routledge.

Gupta, R. (2008). To the analyzing instrument and beyond: Reconstructing evenly hovering attention. Unpublished Masters dissertation, Auckland University of Technology.

Harrington, A., \& Dunne, J. D. (2015). When mindfulness is therapy: Ethical qualms, historical perspectives. American Psychologist, 70, 621-631.

Hayes, S. C. (2002). Acceptance, mindfulness, and science. Clinical Psychology: Science and Practice, 9, 101-106.

Hayes, S. C., Luoma, J. B., Bond, F. W., Masuda, A., \& Lillis, J. (2006). Acceptance and commitment therapy: Model, process and outcomes. Behaviour Research and Therapy, 44, 1-25.

Hobson, R. F. (1985). Forms of feeling: The heart of psychotherapy. London, UK: Tavistock.

Holmes, J. (2013). Book review of Psychoanalysis and psychoanalytic therapies by Jeremy D. Safran. Psychoanalytic Psychology, 30, 102-104.

Hooke, M. T. S. (nd). The internal attitude of the analyst at work: From Freud's free floating attention to Bion's reverie. Retrieved from www.doppiosogno.it/numero13/ing/1.pdf

Jung, C. G. (1978). Psychology and the East. Princeton, NJ: Princeton University Press.

Kernberg, O. (2014). Innovation in psychoanalytic education. New Associations (British Psychoanalytic Council Newsletter), 16, 9-11.

Klein, D. F. (2002). Dodo deliberations. Clinical Psychology: Science and Practice, 9, 28-29.

Kurtz, S. A. (1984). On silence. Psychoanalytic Review, 71, 227-246.

Lane, R. C., Koetting, M. G., \& Bishop, J. (2002). Silence as communication in psychodynamic psychotherapy. Clinical Psychology Review, 22, 1091-1104.

Lear, J. (1998). Open minded: Working out the logic of the soul. Cambridge, MA: Harvard University Press.

Lear, J. (2003). Therapeutic action: An earnest plea for irony. London, UK: Karnac.

Lear, J. (2004). Psychoanalysis and the idea of a moral psychology: memorial to Bernard Williams' philosophy. Inquiry, 47, 515-522.

Lear, J. (2014). Mourning and moral psychology. Psychoanalytic Psychology, 31, 470-481.

Language and Psychoanalysis, 2019, 8 (1), 4-29.

http://dx.doi.org/10.7565/landp.v8i1.1590 
Leone, G. (1995). Zen meditation: A psychoanalytic conceptualization. The Journal of Transpersonal Psychology, 27, 87-94.

Li, C. (2010). When time stood still... Rowan Williams, waiting and psychotherapy. The Journal of Critical Psychology, Counselling and Psychotherapy, 10, 146153.

Li, C. (2018). Where words trap the mind: The bewitchment of psychotherapy. Language and Psychoanalysis, 7, 84-105.

Lin, P., \& Seiden, H. M. (2014). Mindfulness and psychoanalytic psychotherapy: A clinical convergence. Psychoanalytic Psychology. Retrieved from http://dx.doi.org/10.1037/a0038170

Linehan, M. M. (1993). Cognitive-behavioral treatment of borderline personality disorder. New York, NY: Guilford Press.

Loewald, H. W. (1960). On the therapeutic action of psycho-analysis. International Journal of Psycho-Analysis, 41, 16-33.

Lomas, P. (1981). The case for a personal psychotherapy. Oxford, UK: Oxford University Press.

Lomas, P. (1994). Cultivating intuition: An introduction to psychotherapy. London, UK: Penguin.

Lomas, P. (1999). Doing good? Psychotherapy out of its depth. Oxford, UK: Oxford University Press.

Luborsky, L. (2002). The Dodo bird verdict is alive and well - mostly. Clinical Psychology: Science and Practice 9, 2-12.

Mace, C. (2008). Mindfulness and the future of psychotherapy. European Psychotherapy, 8, 123-139.

Maitland, S. (2008). A book of silence. London, UK: Granta.

Makise, H. (2017). Lacanian psychoanalysis and Japanese Zen (Hakuin Zen): The relation between 'the impossible thing', drawings, and topology. Annual Review of Critical Psychology, 13, 1-15 (Page numbers pertain to this paper only, not the entire journal issue). Retrieved from https://discourseunit.com/annualreview/arcp-13-discourse-unit-global-seminar-2017/

McAleavey, A. A., \& Castonguay, L. G. (2015). The process of change in psychotherapy: Common and unique factors. In O. C. G. Gelo, A. Pritz, \& B. Rieken (Eds), Psychotherapy research: Foundations, process, and outcome (pp. 293-310). New York, NY: Springer.

Messer, S. B. (2002). Let's face facts: Common factors are more potent than specific therapy ingredients. Clinical Psychology: Science and Practice, 9, 21-25.

Moncayo, P. (2012). The signifier pointing at the moon: Psychoanalysis and Zen Buddhism. London, UK: Karnac.

Nietzsche, F. (1973). Beyond good and evil: Prelude to a philosophy of the future. Harmondsworth, UK: Penguin Books. (Original work published 1886)

Phillips, A. (2002). Introduction. In Sigmund Freud: Wild analysis (pp. vii-xxv). London, UK: Penguin Books.

Phillips, A. (2014) Becoming Freud: the making of a psychoanalyst. New Haven, CT: Yale University Press.

Proner, B. D. (2006). A word about words. Journal of Analytical Psychology, 51, 423 435.

Reik, T. (1927/1968). The psychological meaning of silence. Psychoanalytic Review, $55,172-186$.

Reik, T. (1948). Listening with the third ear: The inner experience of a psychoanalyst. New York, NY: Farrar, Straus \& Co.

Language and Psychoanalysis, 2019, 8 (1), 4-29.

http://dx.doi.org/10.7565/landp.v8i1.1590 
Rounsaville, B. J., \& Carroll, K. M. (2002). Commentary on Dodo bird revisited:

Why aren't we Dodos yet? Clinical Psychology: Science and Practice 9, 17-20.

Safran, J. D. (Ed.) (2003a). Psychoanalysis and Buddhism: An unfolding dialogue. Somerville, MA: Wisdom Publications.

Safran, J. D. (2003b). Introduction: Psychoanalysis and Buddhism as cultural Institutions. In J. D. Safran (Ed.) Psychoanalysis and Buddhism: An unfolding dialogue (pp. 1-34). Somerville, MA: Wisdom Publications.

Safran, J. D. (2011). Theodor Reik's Listening with the Third Ear and the role of selfanalysis in contemporary psychoanalytic thinking. Psychoanalytic Review, 98, 205-216.

Schneider, K. J. (2002). The Dodo bird: Less a verdict than an opportunity. Clinical Psychology: Science and Practice 9, 26-27.

Segal, Z. V., Williams, J. M. G., \& Teasdale, J. D. (2002). Mindfulness-based cognitive therapy for depression. New York, NY: Guilford Press.

Škodlar, B. (2016). Applications of mindfulness in psychotherapy - Contemporary dilemmas. Asian Studies IV (XX), 2, 123-138.

Sloma, J. T. (2010). Rhythms of psychoanalysis and counterpoints of therapeutic spontaneity. Paper presented at the Annual Meeting of the International Forum for Psychoanalytic Education Nashville, Tennessee, October 29, 2010. Retrieved from https://ifpe.files.wordpress.com/2011/04/rhythms-ofpsychoanalysis1.pdf

Speeth, K. R. (1982). On psychotherapeutic attention. The Journal of Transpersonal Psychology, 14, 141-160.

Suler, J. (1995). In search of the self: Zen Buddhism and psychoanalysis. Psychoanalytic Review, 82, 407-426.

Suzuki, D. T., Fromm, E., \& de Martino, R. (1960). Zen Buddhism and psychoanalysis. London, UK: Allen \& Unwin.

Symington, J., \& Symington, N. (1996). The clinical thinking of Wilfred Bion. London, UK: Routledge.

van Waning, A. (2002). A mindful self and beyond: Sharing in the ongoing dialogue of Buddhism and psychoanalysis. In P. Young-Eisendrath, \& S. Muramoto (Eds.), Awakening and insight Zen Buddhism and psychotherapy (pp. 91-102). Hove East, UK: Brunner-Routledge.

Warin, T. (2007). Silence in psychotherapy: Therapists' difficulties in using silence as a therapeutic technique. Unpublished dissertation, Auckland University of Technology, New Zealand. Retrieved from https://aut.researchgateway.ac.nz/bitstream/handle/10292/9545/WarinT.pdf?seq uence $=1 \&$ is Allowed $=\mathrm{y}$

Weiss, H. (2009). The use of mindfulness in psychodynamic and body oriented psychotherapy. Body, Movement and Dance in Psychotherapy, 4, 5-16.

Williams, R. (2002). Writing in the dust: Reflections on 11th September and its aftermath. London, UK: Hodder \& Stoughton.

Wood, J. (2008). How fiction works. London, UK: Vintage Books.

Young-Eisendrath, P., \& Muramoto, S. (Eds.) (2002). Awakening and insight Zen Buddhism and psychotherapy. Hove East Essex, UK: Brunner-Routledge. 